\title{
Dwi Yulis Susanto | Gaya Kepemimpinan GAYA KEPEMIMPINAN TRANSAKSIONAL DAN NEED FOR ACHIEVEMENT TERHADAP KINERJA KARYAWAN PDAM KOTA MALANG
}

\author{
Dwi Yulis Susanto \\ yulissusanto76@gmail.com \\ Universitas Gajayana Malang
}

\begin{abstract}
Abstrak
Penelitian ini menguji tentang hubungan gaya kepemimpinan transaksional dan need for achevement terhadap kinerja karyawan pada PDAM Kota Malang. Penelitian ini dilakukan di PDAM Kota Malang. Populasi dari penelitian ini adalah karyawan PDAM Kota Malang yang berjumlah 372 pegawai. Metode penelitian kuantitatif dengan menggunakan skala likert dan menggunakan metode regresi linier berganda. Jumlah sampel 190 orang karyawan dari populasi 372 orang karyawan PDAM Kota Malang dengan menggunakan teknik purposive random sampling. Berdasarkan hasil uji hipotesis diketahui bahwa hipotesis pertama ditolak di mana gaya kepemimpinan transaksional secara parsial tidak berpengaruh terhadap kinerja kinerja karayawan, hipotesis kedua diterima, dimana need for achievement berpengaruh positif dan signifikan terhadap kinerja karyawan, hipotesis ketiga diterima, dimana gaya kepemimpinan transaksional dan need for achievement berpengaruh positif dan signifikan secara simulatan terhadap kinerja karyawan. Berdasarkan Hasil koefisien determinasi didapatkan nilai Adjusted $R$ Square sebesar 0,139 artinya bahwa besar pengaruh terhadap variabel kinerja karyawan yang ditimbulkan oleh variabel gaya kepemimpinan transaksional dan need for achievement adalah sebesar 13,9 persen, sedangkan besar pengaruh terhadap variabel kinerja karyawan yang ditimbulkan oleh faktor lain adalah sebesar 86,1 persen
\end{abstract}

Kata Kunci : Gaya Kepemimpinan Transaksional, Need for achievement, Kinerja Karyawan. 


\section{Dwi Yulis Susanto | Gaya Kepemimpinan}

\section{Abstract}

This study examines interconnection between transactional leadership and need for achevement to employee performance in PDAM Malang. This research was conducted in PDAM Malang City. The population of this study are employees of PDAM Malang City amounting to 372 employees. Quantitative research method using Likert scale and using multiple linear regression method. The number of samples of 190 employees from the population of 372 employees PDAM Malang City by using purposive random sampling technique. Based on the result of hypothesis test, first hypothesis rejected which is no effect on the performance of the employee, the second hypothesis is accepted, wherever the need for achievement shows positive and significant effect on the employee performance, and the last hypothesis is accepted, it is persue just as positive and significant influence simultaneously on employee performance. Based on the determination coefficient obtained Adjusted R Square value of 0.139 means that the influence of employee performance variables caused by transactional leadership style variables and need for achievement is 13.9 percent, while the big influence on employee performance variables caused by other factors is by 86.1 percent Keywords: Transactional Leadership Style, Need for achievement, Employee Performance.

Keywords : Transactional Leadership, Need for achievement, Employee Performance 


\section{Dwi Yulis Susanto | Gaya Kepemimpinan}

\section{Latar Belakang Masalah}

Sumber daya manusia merupakan pokok atau inti dalam sebuah organisasi ataupun sebuah perusahaan. Agar seluruh aktivitas perusahaan berjalan dengan baik, perusahaan harus memiliki karyawan yang berpengalaman dan berpengetahuan tinggi serta upaya untuk mengelola perusahaan semaksimal mungkin sehingga kinerja karyawan dapat meningkat. Menurut Donnelly (2003) kinerja merupakan tingkat keberhasilan di dalam melaksanakan tugas serta kemampuan untuk mencapai tujuan yang telah ditetapkan. Kinerja dikatakan baik dan sukses jika tujuan yang diinginkan dapat dicapai dengan baik.

Upaya pengembangan karyawan sebuah perusahaan merupakan unsur yang paling dominan dalam proses peningkatan mutu yang dilakukan serta dalam rangka kompetensi untuk meningkatkan kinerjanya. Di era globalisasi sekarang ini, peningkatan kinerja karyawan akan membawa kemajuan secara signifikan bagi perusahaan untuk dapat bertahan dalam menghadapi persaingan bisnis yang tidak stabil. Oleh karena perlu adanya upaya-upaya yang dilakukan dalam rangka meningkatkan kinerja karyawan. Peningkatan kinerja karyawan merupakan tantangan manajemen yang paling penting, karena keberhasilan untuk mencapai tujuan dan kelangsungan hidup perusahaan tergantung pada kualitas sumber daya manusia yang ada di dalamnya.

Kinerja yang baik adalah kinerja yang optimal, yaitu kinerja yang sesuai standar perusahaan dan mendukung tujuan perusahaan. Kinerja karyawan yang mempunyai loyalitas yang tinggi sangatlah diharapkan oleh perusahaan. Semakin banyak karyawan yang mempunyai loyalitas kinerja yang tinggi, maka produktivitas perusahaan secara keseluruhan akan meningkat sehingga perusahaan dapat bertahan hidup serta mengembangkan usahanya. Karyawan dituntut untuk mampu menyelesaikan tugas dan tanggung jawabnya secara efektif dan efisien. Tercapainya tujuan sebuah perusahaan tidak hanya tergantung pada peralatan yang memadai, sarana dan prasarana 


\section{Dwi Yulis Susanto | Gaya Kepemimpinan}

yang lengkap, tetapi justru lebih tergantung pada kualitas sumber daya manusia yang melaksanakan tanggung jawab tersebut.

Setiap perusahaan akan berlomba-lomba dalam rangka meningkatkan kinerja individu karyawannya, dengan harapan apa yang menjadi tujuan dari perusahaan tersebut akan tercapai. Ada beberapa faktor yang dapat diukur dalam keberhasilan karyawan, di antaranya kepuasan konsumen, berkurangnya jumlah keluhan, dan tercapainya laba yang maksimal.

Menurut Rivai dan Mulyadi (2010) faktor pertama yang diidentifikasikan mempengaruhi kinerja karyawan adalah kepemimpinan. Pemimpin dengan gaya kepemimpinannya menentukan strategi organisasi, baik jangka panjang maupun jangka pendek. Kepemimpinan adalah proses mempengaruhi dalam menentukan tujuan organisasi, memotivasi perilaku pengikut untuk mencapai tujuan, mempengaruhi untuk memperbaiki kelompok dan budayanya.

Menurut penelitian Hardjanti dan Rahadhini (2011) prestasi kerja yang efektif hanya dapat dicapai dengan mencocokkan pemimpin dengan situasi, atau dengan mengubah situasi agar cocok dengan pemimpin. Kepemimpinan yang efektif tergantung pada sejumlah faktor tertentu, sehingga tidak ada kepemimpinan yang efektif untuk semua situasi.

Gaya kepemimpinan yang tepat akan menimbulkan motivasi seseorang untuk berprestasi. Sukses atau tidaknya karyawan dalam prestasi kerja dipengaruhi oleh gaya kepemimpinan atasannya. Gaya kepemimpinan cocok apabila tujuan perusahaan telah dikomunikasikan dan bawahan telah menerimanya. Seorang pemimpin harus menerapkan gaya kepemimpinan untuk mengelola bawahannya, karena seorang pemimpin akan sangat mempengaruhi keberhasilan perusahaan dalam mencapai tujuannya. Widyatmini dan Hakim (2008), Sukmawati (2008) dalam penelitiannya menyatakan bahwa gaya kepemimpinan mempunyai pengaruh yang signifikan terhadap kinerja karyawan. 


\section{Dwi Yulis Susanto | Gaya Kepemimpinan}

Tidak hanya faktor gaya kepemimpinan saja yang perlu diperhatikan oleh perusahaan guna meningkatkan kinerja karyawan, akan tetapi perusahaan juga harus memperhatikan faktor motivasi kerja. Menurut penelitian Murty dan Hudiwinarsih (2012) motivasi secara sederhana dapat dirumuskan sebagai kondisi atau tindakan yang mendorong seseorang untuk melakukan sebuah pekerjaan atau kegiatan semaksimal mungkin untuk berbuat dan berproduksi.

Menurut penelitian Damayanti et al., (2013) pemahaman terhadap motivasi karyawan akan sangat penting kaitannya dengan pencapaian tujuan, yaitu prestasi kerja atau kinerja dan efisiensi. Pemberian motivasi merupakan salah satu tujuan agar karyawan yang diberi motivasi dapat bekerja sesuai dengan acuan kerja.

Keberadaan PDAM di berbagai daerah merupakan perusahaan pemerintah yang pengelolaannya dibawah tanggung jawab pemerintah daerah yang diharapkan dapat melayani masyarakat serta tetap mendapatkan profit atau keuntungan. Salah satu cara untuk mempertahankan atau meningkatkan efektivitas perusahaan dalam mencapai tujuannya adalah dengan memperbaiki dan mengembangkan keunggulan komparatif di bidang sumber daya manusia (Bangun, 2012). Keberhasilan manajemen dalam kegiatan operasional perusahaan dapat diukur dari hasil operasional perusahaan yang disebut dengan kinerja perusahaan Dengan peningkatan jumlah penduduk yang ada di Kota Malang pihak PDAM harus berani mengambil tindakan strategi dalam mengatasi kekurangan produksi air, karena apabila peningkatan jumlah penduduk tidak di ikuti oleh peningkatan kinerja perusahaan kemungkinan yang akan tejadi adalah penurunan reputasi PDAM dimata masyarakat. Peningkatan sistem manajemen perusahaan yang ada akan bermanfaat dalam operasional perusahaan.

Peningkatan manajemen bisa melalui pendidikan dan pelatihan. Segi manajemen yang perlu ditingkatkan antara lain adalah sistem pelayanan yang digunakan, karena sistem 


\section{Dwi Yulis Susanto | Gaya Kepemimpinan}

pelayanan merupakan hal yang sangat penting karena berhubungan dengan konsumen, terlebih lagi dengan adanya implementasi Undang-Undang No.25 Tahun 2009 tentang pelayanan publik yang memungkinkan konsumen melayangkan gugatan atau tuntutan atas ketidakpuasan pelayanan yang diberikan oleh PDAM. Apabila sistem pelayanan memenuhi kreteria yang diinginkan konsumen maka sudah tentu menjadikan perusahaan lebih tangguh.

PDAM Kota Malang sebagai salah satu Badan Usaha Milik Daerah (BUMD), dengan citra baik yang didapat PDAM Kota Malang salah satunya adalah penghargaan Global Water Award, di Uni Emirate Arab tahun 2016. Berkat inovasi Produk Zona Air Minum Prima (ZAMP) serta pilot project 100-0-100, yang satu poinnya 100 persen terlayaninya air bersih, mendapat perhatian khusus dari dunia internasional penghargaan ini sangat membanggakan khususnya bagi masyarakat Malang. (www.malangtimes.com).

Dari beberapa prestasi yang didapat oleh PDAM Kota Malang peneliti menduga ada pengaruh gaya kepemimpinan transaksional dan Need for Achivement yang berpengaruh tehadap kinerja karyawan sehingga PDAM kota Malang mendapatkan prestasi atau penghargaan tersebut. Berdasarkan wawancara yang dilakukan peneliti terhadap beberapa orang karyawan PDAM Kota Malang, mengemukakan bahwa karyawan mampu bekerja secara mandiri didalam mengerjakan pekerjaannya. Hal ini disebabkan karena adanya jadwal kerja dan SOP (Standard Operational Procedure) yang jelas mengenai hal-hal apa saja yang harus dikerjakan setiap harinya. Begitupun dengan komunikasi yang terjadi dalam perusahan baik antara pimpinan dan karyawan maupun sesama karyawan terjalin dengan baik.

Selain itu, sejak Januari tahun 2014 PDAM Kota Malang menerapkan sistem penilaian kinerja yang lebih obyektif dan efektif untuk meningkatkan kinerja pegawai. Hal ini dimaksudkan agar pegawai termotivasi untuk bekerja lebih baik dan memberikan kontribusi sesuai dengan kemampuan yang 


\section{Dwi Yulis Susanto | Gaya Kepemimpinan}

dimilikinya. Sistem penilaian kinerja pegawai dilakukan dengan menilai aspek perilaku dan aspek sasaran kerja. Nilai total kinerja merupakan gabungan dari nilai perilaku dan nilai pencapaian sasaran kerja dengan bobot masing-masing 40\% dan 60\%. Pegawai dengan kinerja lebih tinggi akan memperoleh imbalan yang lebih tinggi. Sedangkan pegawai dengan kinerja buruk akan mendapatkan sanksi mulai dari ringan sampai dengan pemberhentian

Berdasarkan hasil wawancara yang telah dilakukan terlihat bahwa kinerja karyawan sangat ditentukan pada jadwal kerja dan SOP (Standard Operational Procedure) yang sudah ada dan jelas serta jenis pekerjaan yang dilakukan oleh karyawan bersifat konstan (sama setiap harinya), maka hal ini merupakan alasan dari tercapainya beberpaa prestasi yang pernah didapat PDAM Kota Malang.

Dari latar belakang dan penelitian tersebut diatas dapat ditarik sebuah kesimpulan bahwa kinerja karyawan merupakan faktor utama pendukung dalam menjalankan strategi organisasi, untuk meningkatkan kinerja karyawan maka perlu dilakukan penelitian pada variabel-variabel yang saling mempengaruhi tersebut.

\section{Kepemimpinan}

Kepemimpinan merupakan suatu proses dengan berbagai cara mempengaruhi orang atau sekelompok orang untuk mencapai tujuan bersama (Keating, 1991). Kepemimpinan adalah meliputi proses mempengaruhi dalam menentukan tujuan organisani, memotivasi, perilaku pengikut untuk mencapai tujuan, mempengaruhi untuk memperbaiki kelompok dan budayanya (Rivai, 2003).

Kepemimpinan dalam konteks suatu organisasi, adalah kemampuan dan keterampilan seseorang yang menduduki jabatan sebagai pimpinan satuan kerja untuk mempengaruhi perilaku orang lain, terutama bawahannya, untuk berpikir dan bertindak sedemikian rupa, sehingga melalui perilaku yang 


\section{Dwi Yulis Susanto | Gaya Kepemimpinan}

positif, ia memberikan sumbangsih nyata dalam pencapaian tujuan organisasi (Siagian, 2003).

Berdasarkan definisi di atas, dapat disimpulkan kepemimpinan merupakan suatu proses mempengaruhi orang lain atau sekelompok orang untuk mencapai tujuan bersama.

\section{Pengertian Gaya Kepemimpinan}

Menurut Riberu, (dalam Siti Maria Uzlah, 2011) gaya kepemimpinan adalah cara pemimpin membawa diri sebagai pemimpin dan tampil dalam menggunakan kekuasaannya. Menurut Riberu gaya kepemimpinan tidak hanya tergantung dari sifat pribadi si pemimpin tetapi juga dari iklim yang sudah ditentukan oleh iklim yang sudah ditentukan oleh struktur dan kebudayaan kelompok. Unsur-unsur yang mendasari kepemimpinan antara lain: kemampuan mempengaruhi orang lain, kemampuan mengarahkan-memotivasi tingkah laku orang lainkelompok, adanya unsur kerjasama untuk mencapai tujuan yang diinginkan

Gaya kepemimpinan adalah perilaku atau tindakan pemimpin dalam mempengaruhi para anggota atau pengikut dalam melaksanakan tugas - tugas pekerjaan manajerialnya Menurut Soekarso (2010). Berdasarkan definisi diatas dapat disimpulkan bahwa gaya kepemimpinan adalah pola perilaku menetap yang ditunjukkan ketika berusaha mempengaruhi kegiatan - kegiatan karyawan yang diketahui dan dirasakan oleh karyawan.

\section{Kepemimpinan Transaksional}

Menurut Bass (1994) kepemimpinan transaksional muncul ketika kepemimpinannya lebih menekankan pada transaksi interpersonal antara pemimpin dan pegawainya yang melibatkan hubungan pertukaran. Pegawai memperoleh imbalan segera dan nyata apabila memenuhi perintah pemimpin. Maka secara rinci dapat dijelaskan, seorang pemimpin transaksional memiliki karakteristik sebagai berikut: contingent reward,

\section{2 | Journal An-nafs: Vol. 3 No. 1 Juni 2018}




\section{Dwi Yulis Susanto | Gaya Kepemimpinan}

management by exeption (active), dan management by exeption (passive). Contingent Reward, artinya pemimpin menjanjikan imbalan kepada para pegawai untuk kinerja yang baik dan pemimpin menghargai prestasi kerja. Management By Exeption (active), artinya mengawasi pelaksanaan tugas pekerjaan pegawainya agar mereka tidak membuat kesalahan - kesalahan atau agar mereka tidak gagal dalam melaksanakan pekerjaan, atau agar kesalahan dan kegagalan pegawai dapat secepatnya diketahui untuk diperbaiki. Management By Exeption (passive), artinya melakukan tindakan setelah terjadi kegagalan pegawai untuk mencapai tujuan, atau setelah benarbenar timbul masalah yang serius, pemimpin berpandangan bahwa atasan belum akan bertindak jika belum ada kegagalan. Pegawai mendapat kesempatan untuk berupaya memperbaiki unjuk kerjanya, mengatasi masalahnya, dan mengoreksi kesalahannya.

\section{Teori Motivasi}

Motivasi adalah serangkaian sikap dan nilai-nilai yang mempengaruhi individu untuk mencapai hal yang spesifik sesuai dengan tujuan individu (Rivai \& Sagala, 2009), Koontz (dalam Notoatmodjo, 2009) mendefinisikan motivasi yaitu "motivasi mengacu pada dorongan dan usaha untuk memuaskan kebutuhan atau suatu tujuan". Berdasarkan definisi motivasi yang telah dirumuskan oleh para ahli, dapat disimpulkan bahwa motivasi merupakan suatu dorongan yang dimiliki oleh setiap individu dalam mengerahkan kemampuan dan keterampilannya dalam tujuan untuk memenuhi kebutuhan-kebutuhan fisiologis dan psikologis yang nantinya berdampak pada pencapaian kinerja yang optimal.

Teori motivasi sendiri dibagi menjadi dua yaitu: Teori Proses dan Teori Kepuasan. Teori proses menekankan pada bagaimana dan dengan tujuan apa setiap individu didorong agar melakukan tugasnya dengan maksimal. Teori proses ini dianut oleh Edwin Locke dengan teori penetapan tujuan, Victor Vroom 


\section{Dwi Yulis Susanto | Gaya Kepemimpinan}

dengan teori harapan, Stacy Adams dengan teori keadilan, serta Porter dan Lawler dengan teori kepuasan kinerja.

Sedangkan, teori kepuasan menjelaskan arti pentingnya pemahaman faktor-faktor yang ada di dalam individu yang menyebabkan mereka bertingkah laku tertentu. Teori ini membahas bahwa individu memiliki kebutuhan-kebutuhan fisiologis dan psikologis tertentu yang memuaskan seseorang dan penyebab seseorang itu termotivasi melakukan sesuatu untuk memenuhi kepuasan tersebut.

Teori Trikotomi Kebutuhan McClelland McClelland dalam Mangkunegara (2009) dalam teorinya menyatakan bahwa produktivitas seseorang dipengaruhi oleh "virus mental" yang ada di dalam dirinya. Virus mental adalah kondisi jiwa yang mendorong seseorang untuk dapat mencapai hasil yang maksimal. Virus mental yang dimaksud adalah kebutuhan akan prestasi, kebutuhan akan kekuasaan, dan kebutuhan akan afiliasi.

\section{Kebutuhan Prestasi}

Menurut Kamus Besar Bahasa Indonesia, prestasi adalah hasil yang telah dicapai. Prestasi dapat dicapai dengan menggunakan kemampuan intelektual, spiritual, dan emosional, serta ketahanan diri terhadap segala situasi dalam aspek kehidupan. Kebutuhan Prestasi akan mendorong seseorang berprestasi dalam keadaan bila target yang akan dicapai nyata dan memiliki peluang untuk diperoleh serta cenderung menimbulkan kreatifitas pada seseorang.

Kebutuhan Prestasi dirumuskan dan menetapkan bahwa pencapaian perilaku yang terkait adalah hasil dari konflik antara harapan sukses dan takut gagal. Kecenderungan pendekatan dan penghindaran terdiri dari fungsi kebutuhan pencapaian, harapan dari keberhasilan dan kegagalan, dan nilai insentif dari keberhasilan dan kegagalan.

\section{Kebutuhan Kekuasaan}

Kekuasaan adalah kemampuan individu atau kelompok untuk mempengaruhi tingkah laku orang atau kelompok lain sesuai dengan keinginan individu tersebut. Seseorang yang 


\section{Dwi Yulis Susanto | Gaya Kepemimpinan}

memiliki tingkat Kebutuhan Kekuasaan yang tinggi cenderung berperilaku lebih tegas. Veroff dalam Nindyati (2014) mendefinisikan tujuan kebutuhan kekuasaan sebagai mengerahkan pengaruh dan mencari peningkatan subkategori yang sudah ditetapkan sebagai bagian dari tujuan perilaku untuk memperoleh kebutuhan prestasi.

\section{Kebutuhan Afiliasi}

Afiliasi merupakan pembentukan kontak sosial yang menghasilkan sebuah hubungan atau pertalian. Seseorang yang memiliki kebutuhan seperti ini tentu mereka memiliki motivasi untuk persahabatan, menanggung dan bekerja sama daripada sebagai ajang kompetisi di dalam suatu organisasi.

McClelland dalam Nindyati (2014) menjelaskan bahwa karakter individu dengan Kebutuhan Afiliasi yang tinggi cenderung dapat menjaga hubungan sosial dengan baik, tidak bisa berada di dalam kondisi yang kompetitif, nyaman dalam norma dan harapan orang lain serta cocok dalam pekerjaan yang membutuhkan kerjasama tim.

\section{Motivasi Berprestasi \\ Definisi Motivasi Berprestasi}

Murray (dalam Chaplin, 2004) mendefinisikan motivasi berprestasi sebagai motif untuk mengatasi rintangan-rintangan atau berusaha melaksanakan secepat dan sebaik mungkin pekerjaan yang ada. Selain itu menurut McClelland, Atkinson, Clark, \& Lowell (dalam Meinawati, 2007) motivasi berprestasi merupakan tujuan dari individu agar berhasil dalam persaingan dengan standar tinggi. Individu mungkin gagal mencapai tujuan ini, tetapi memungkinkan individu tersebut untuk mengidefikasikan tujuan yang akan dicapai. McClelland mengemukan bahwa motivasi berprestasi adalah dorongan untuk melakukan sesuatu dengan lebih baik atau lebih efisien dari pada yang dikerjakan sebelumnya serta lebih berorientasi pada pekerjaan atau tugas (Robbins, 1986). 


\section{Dwi Yulis Susanto | Gaya Kepemimpinan}

McClelland mengemukakan bahwa motivasi berprestasi berkaitan dengan hasrat atau keinginan individu untuk melakukan segala sesuatu dengan sebaik-baiknya, bukan untuk memperoleh penghargaan social atau prestasi melainkan untuk mencapai kepuasan dalam dirinya. McClelland juga mengemukakan bahwa orang yang memiliki motivasi berprestasi yang tinggi akan lebih memperhatikan hal-hal yang berhubungan dengan perbaikan kinerja dan belajar lebih baik.

Menurut McClelland dan Atkinson (dalam Rahmawati, 2006), motivasi yang paling penting untuk pendidikan adalah motivasi berprestasi, dimana seseorang cenderung berjuang untuk mencapai sukses atau memilih suatu kegiatan yang berorientasi untuk tujuan sukses atau gagal.

Ciri Motivasi Berprestasi Ada beberapa karakteristik dari individu yang memiliki motivasi berprestasi yang dijabarkan oleh McClelland (1987), yakni sebagai berikut:

a. Menyukai tugas yang memiliki taraf kesulitan sedang

b. Bertanggung jawab secara personal atas performa kerja

c. Menyukai umpan balik

d. Inovatif Mereka yang memiliki motivasi berprestasi Ketahanan

\section{Metode Penelitian}

Metode penelitian yang digunakan adalah penelitian kuantitatif, karena hasil dari data penelitian yang diperoleh berupa angka-angka dan akan dianalisis menggunakan statistik (Sugiyono, 2008). Penelitian ini terdiri dari tiga variabel yaitu gaya kepemimpinan transaksional, need for achievement dan kinerja karayawan

Populasi adalah wilayah generalisasi yang terdiri dari obyek/subyek yang mempunyai kualitas dan karakteristik tertentu yang ditetapkan oleh peneliti untuk dipelajari dan kemudian ditarik kesimpulannya (Sugiyono,2010). Populasi dalam penelitian ini adalah seluruh karyawan yang bekerja pada 


\section{Dwi Yulis Susanto | Gaya Kepemimpinan}

Perusahaan Daerah Air Minum (PDAM) Kota Malang yang berjumlah 372 karyawan.

Sampel penelitian adalah bagian dari jumlah dan karakteristik yang dimiliki oleh populasi tersebut (Sugiyono,2008). Peneliti menggunakan rumus Slovin untuk menentukan jumlah sample yang sesuai dengan jumlah populasi, dengan rumus Slovin didapatkan jumlah sample sebanyak 190 orang karyawan.

Dalam penelitian ini peneliti menggunakan teknik purposive random sampling. Purposive random sampling adalah penentuan sampel dengan pertimbangan tertentu (Sugiyono, 2012). Artinya digunakannya teknik purposive random sampling karena penelitian sudah menetapkan terlebih dahulu sampel yang akan dipakai untuk penelitian sesuai dengan tujuan penelitian. Teknik ini dilakukan karena beberapa pertimbangan, yaitu keterbatasan waktu, tenaga dan dana sehingga tidak dapat mengambil sampel yang besar dan jauh.

Metode pengumpulan data yang digunakan berbentuk kuesioner dengan skala Model Likert.

\section{Hasil dan Pembahasan}

\section{Gambaran Umum Subjek Penelitian}

Berikut ini akan diuraikan mengenai gambaran subjek penelitian. Diawali dengan Usia, jenis kelamin, pendidikan dan lama bekerja. Penelitian ini melibatkan 190 sampel penelitian yang diambil dari PDAM Kota Malang dengan jumlah populasi 372 karyawan.

\section{Jenis Kelamin}

Tabel 1

Karakteristik Karyawan Berdasarkan Jenis Kelamin

\begin{tabular}{|c|c|c|}
\hline $\begin{array}{c}\text { Jenis } \\
\text { Kelamin }\end{array}$ & Jumlah & Persentase \\
\hline Pria & 273 & $73 \%$ \\
\hline Wanita & 99 & $27 \%$ \\
\hline Total & $\mathbf{3 7 2}$ & $\mathbf{1 0 0} \%$ \\
\hline
\end{tabular}


Dwi Yulis Susanto | Gaya Kepemimpinan

Usia

Tabel 2

Karakteristik Karyawan Berdasarkan Usia

\begin{tabular}{|c|c|c|c|}
\hline No & Kelompok Usia & Jumlah & Persentase \\
\hline 1 & $<30$ & 19 & $5,1 \%$ \\
\hline 2 & $>30-35$ & 18 & $8,0 \%$ \\
\hline 3 & $>35-40$ & 48 & $12,9 \%$ \\
\hline 4 & $>40-45$ & 130 & $34,9 \%$ \\
\hline 5 & $>45-50$ & 110 & $29,5 \%$ \\
\hline 6 & $>50$ & 47 & $12,6 \%$ \\
\hline \multicolumn{2}{|c|}{ Total } & $\mathbf{3 7 2}$ & \\
\hline
\end{tabular}

Tingkat Pendidikan

Tabel 3

Karakteristik Karyawan Berdasarkan tingkat Pendidikan

Terakhir

\begin{tabular}{|c|c|c|}
\hline Pendidikan Formal & Jumlah & Persentase \\
\hline - S2 & 21 & $5,6 \%$ \\
\hline - Sarjana / S1 & 214 & $57,5 \%$ \\
\hline - Sarjana Muda / D3 & 6 & $1,6 \%$ \\
\hline - D 1 & 2 & $0,5 \%$ \\
\hline - SLTA & 117 & $31,4 \%$ \\
\hline - SLTP & 12 & $3,2 \%$ \\
\hline Total & 372 & \\
\hline
\end{tabular}

Lama Kerja

Tabel 4

Karakteristik Karyawan Berdasarkan Lama Kerja

\begin{tabular}{|c|c|c|}
\hline Lama Kerja & Jumlah & Persentase \\
\hline$\leq 10$ tahun & 22 & $11.6 \%$ \\
\hline $11-20$ tahun & 38 & $20.0 \%$ \\
\hline $21-30$ tahun & 126 & $66.3 \%$ \\
\hline$>30$ tahun & 4 & $2.1 \%$ \\
\hline Total & 168 & $88.4 \%$ \\
\hline
\end{tabular}

\section{Uji Asumsi Klasik}

Uji asumsi klasik digunakan untuk mengetahui ketepatan data. Sebuah model regresi akan digunakan untuk melakukan 


\section{Dwi Yulis Susanto | Gaya Kepemimpinan}

peramalan sebuah model yang baik adalah model dengan kesalahan peramalan yang seminimal mungkin. Karena itu, sebuah model sebelum digunakan seharusnya memenuhi beberapa asumsi, yang biasa disebut asumsi klasik (singgih santoso, 2009).

Asumsi klasik yang digunakan dalam penelitian ini adalah normalitas, multikolinieritas, dan heteroskedastisitas.

\section{a. Uji Normalitas}

Tujuan uji normalitas adalah untuk mengetahui apakah distribusi sebuah data mengikuti atau mendekati distribusi normal. Uji normalitas dilakukan dengan menggunakan pendekatan Kolmogrov-Smirnov. Dengan menggunakan tingkat signifikan 5\% maka jika nilai Asymp.Sig. (2-tailed) diatas nilai signifikan $5 \%$ artinya variabel residual berdistribusi normal (Situmorang, 2010).

Berikut disajikan hasil pengujian asumsi normalitas dengan menggunakan uji Kolmogorov-Smirnov.

\section{Tabel 4}

Uji Kolmogorov-Smirnov

\begin{tabular}{|l|l|}
\hline & $\begin{array}{l}\text { Unstandardized } \\
\text { Residual }\end{array}$ \\
\hline Kolmogorov-Smirnov Z & 1.165 \\
\hline Asymp. Sig. (2-tailed) & 133 \\
\hline
\end{tabular}

Hasil pengujian asumsi normalitas dengan uji Kolmogorov-Smirnov didapatkan nilai signfikansi $(0,133)$ lebih dari alpha $(0,050)$ sehingga asumsi normalitas terpenuhi.

\section{b. Uji Heteroskedastisitas}

Model regresi yang baik adalah tidak terjadi heteroskedastisitas. Heteroskedastisitas diuji dengan menggunakan uji Glejser dengan pengambilan keputusan jika variabel independen signifikan secara statistik mempengaruhi variabel dependen, maka ada indikasi terjadinya heteroskedastisitas. Jika probabilitas signifikannya diatas tingkat kepercayaan 5\% dapat disimpulkan model regresi tidak mengarah adanya heteroskedastisitas 


\section{Dwi Yulis Susanto | Gaya Kepemimpinan}

Berikut disajikan hasil pengujian asumsi heteroskedastisitas dengan menggunakan uji Glejser.

Tabel 4 Uji Glejser

\begin{tabular}{|c|c|c|c|}
\hline \multicolumn{2}{|c|}{ Model } & $\mathrm{t}$ & Sig. \\
\hline \multirow{3}{*}{1} & (Constant) & -.235 & .815 \\
\hline \multirow{3}{*}{1} & $\begin{array}{c}\text { Gaya Kepemimpinan } \\
\text { Transaksional }\end{array}$ & 1.369 & .173 \\
\cline { 2 - 4 } & Need For Achivement & .083 & .934 \\
\hline
\end{tabular}

Hasil pengujian asumsi heteroskedastisitas dengan menggunakan uji Glejser didapatkan nilai signifikansi pada masing-masing variabel lebih dari alpha $(0,050)$, sehingga tidak ada indikasi heteroskedastisitas pada variabel bebas yang digunakan.

\section{c. Asumsi Multikolinieritas}

Tujuan dari uji multikolinieritas adalah untuk mengetahui variabel independen yang satu dengan yang lain dalam model regresi berganda tidak saling berhubungan secara sempurna. Untuk mengetahui ada tidaknya gejala multikolinearitas dapat dilihat dari besarnya nilai Tolerance dan VIF (Variance Inflation Factor) melalui program SPSS. Tolerance mengukur variabilitas variabel terpilih yang tidak dijelaskan oleh variabel independen lainnya. Nilai umum yang biasa dipakai adalah nilai Tolerance $>1$ atau nilai VIF $<5$, maka tidak terjadi multikolinearitas (Situmorang, 2010).

Berikut disajikan hasil pengujian asumsi multikolinieritas dengan menggunakan Variance Inflation Factor (VIF). 
Dwi Yulis Susanto | Gaya Kepemimpinan

Tabel 4

Uji Variance Inflation Factor

\begin{tabular}{|c|c|c|c|}
\hline \multicolumn{2}{|c|}{ Model } & \multicolumn{2}{c|}{ Collinearity Statistics } \\
\cline { 3 - 4 } \multicolumn{1}{c|}{} & Tolerance & VIF \\
\hline \multirow{4}{*}{1} & $\begin{array}{c}\text { Gaya } \\
\text { Kepemimpinan } \\
\text { Transaksional }\end{array}$ & .955 & 1.047 \\
\cline { 2 - 4 } & $\begin{array}{c}\text { Need For } \\
\text { Achivement }\end{array}$ & .955 & 1.047 \\
\hline
\end{tabular}

Hasil pengujian asumsi multikolnieritas dengan menggunakan VIF didapatkan nilai VIF pada masing-masing variabel kurang dari sepuluh $(<10)$, sehingga tidak ada indikasi multikolinieritas pada variabel bebas yang digunakan.

\section{Analisis Regresi Linier Berganda}

Berikut disajikan hasil regresi linier berganda antara variabel gaya kepemimpinan transaksional dan Need For Achivement terhadap kinerja karyawan.

Tabel 4

Regresi Linier Berganda

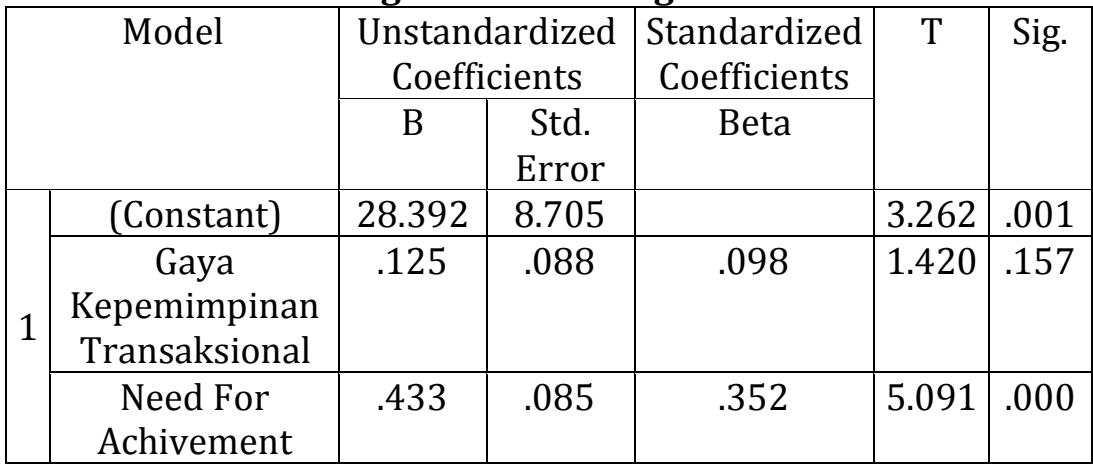

Hasil persamaan regresi linier antara gaya kepemimpinan transaksional dan Need For Achivement terhadap kinerja karyawan disajikan sebagai berikut:

$$
\begin{aligned}
& \mathrm{Y}=a+b 1 \mathrm{X} 1+b 2 \mathrm{X} 2+\mathrm{e} \\
& \mathrm{Y}=28.392+0.125 \mathrm{X} 1+0.433 \mathrm{X} 2+\mathrm{e}
\end{aligned}
$$

Dari persamaan tersebut dapat dijabarkan sebagai berkut:

a) Nilai konstanta (a) sebesar 28,392 menunjukkan bahwa tanpa adanya pengaruh dari gaya kepemimpinan transaksional dan 


\section{Dwi Yulis Susanto | Gaya Kepemimpinan}

Need For Achivement maka kinerja karyawan siswa sebesar 28,392 .

b) Nilai koefisien gaya kepemimpinan transaksional (b1) sebesar 0,125 menunjukkan bahwa semakin baik gaya kepemimpinan transaksional maka akan semakin meningkatkan kinerja karyawan.

c) Nilai koefisien Need For Achivement (b2) sebesar 0,433 menunjukkan bahwa semakin baik Need For Achivement maka akan semakin meningkatkan kinerja karyawan

\section{Pengujian Hipotesis}

Pengujian hipotesis dilakukan untuk menguji hipotesis yang diajukan. Hipotesis yang diajukan dalam penelitian ini terkait variabel gaya kepemimpinan transaksional dan Need For Achivement terhadap kinerja karyawan. Analisis regresi berganda dipilih untuk menganalisis pengajuan hipotesis dalam penelitian ini.

Berikut disajikan hasil pengujian hipotesis antara variabel gaya kepemimpinan transaksional dan Need For Achivement terhadap kinerja karyawan dengan menggunakan uji simultan (uji F), koefisien determinasi $\left(R^{2}\right)$, dan uji parsial (uji t).

\section{a. Uji Simultan (Uji-F)}

Berikut disajikan hasil pengujian pengaruh antara variabel gaya kepemimpinan transaksional dan Need For Achivement terhadap kinerja karyawan secara simultan dengan menggunakan uji F.

\section{Tabel 4}

\section{Hasil Uji F}

\begin{tabular}{|l|l|l|c|c|c|c|}
\hline \multicolumn{2}{|c|}{ Model } & \multicolumn{1}{|c|}{$\begin{array}{c}\text { Sum of } \\
\text { Squares }\end{array}$} & Df & $\begin{array}{c}\text { Mean } \\
\text { Square }\end{array}$ & F & Sig. \\
\hline \multirow{4}{*}{1} & $\begin{array}{l}\text { Regressio } \\
\mathrm{n}\end{array}$ & 1462.992 & 2 & 731.496 & $\begin{array}{l}16.21 \\
9\end{array}$ & $.000^{\mathrm{b}}$ \\
\cline { 2 - 7 } & Residual & 8433.772 & 187 & 45.100 & & \\
\cline { 2 - 7 } & Total & 9896.763 & 189 & & & \\
\hline
\end{tabular}




\section{Dwi Yulis Susanto | Gaya Kepemimpinan}

Hasil pengujian secara simultan dengan uji $\mathrm{F}$ didapatkan nilai $F$ hitung $(16,219)$ lebih dari $F$ tabel $(3,044)$ atau nilai signifikansi $(0,000)$ kurang dari alpha $(0,050)$ menunjukkan terdapat pengaruh signifikan antara variabel gaya kepemimpinan transaksional dan Need For Achivement terhadap kinerja karyawan secara simultan.

\section{b. Koefisien Determinasi $\left(\mathbf{R}^{2}\right)$}

Berikut disajikan hasil koefisien determinasi antara variabel gaya kepemimpinan transaksional dan Need For Achivement terhadap kinerja karyawan dengan menggunakan $\mathrm{R}^{2}$.

\section{Tabel 4.12}

\section{Koefisien Determinasi R2}

Hasil koefisien determinasi didapatkan nilai Adjusted R

\begin{tabular}{|c|c|c|}
\hline $\mathrm{R}$ & R Square & Adjusted R Square \\
\hline $.384^{\mathrm{a}}$ & .148 & .139 \\
\hline
\end{tabular}

Square sebesar 0,139 artinya bahwa besar pengaruh terhadap variabel kinerja karyawan yang ditimbulkan oleh variabel gaya kepemimpinan transaksional dan Need For Achivement adalah sebesar 13,9 persen, sedangkan besar pengaruh terhadap variabel kinerja karyawan yang ditimbulkan oleh faktor lain adalah sebesar 86,1 persen.

\section{c. Uji Parsial (Uji-t)}

Berikut disajikan hasil pengujian pengaruh antara variabel gaya kepemimpinan transaksional dan Need For Achivement terhadap kinerja karyawan secara parsial dengan menggunakan uji t.

\section{Tabel 4}

Hasil Uji t

\begin{tabular}{|c|c|c|c|}
\hline \multirow{2}{*}{ Model } & $\mathbf{T}$ & Sig. & \multirow{2}{*}{} \\
\hline \multirow{3}{*}{1} & $\begin{array}{c}\text { (Constant) } \\
\text { Gaya kepemimpinan } \\
\text { transaksional }\end{array}$ & 3.262 & .001 \\
\cline { 2 - 4 } & Need For Achivement & 5.420 & .157 \\
\hline
\end{tabular}




\section{Dwi Yulis Susanto | Gaya Kepemimpinan}

a. Uji parsial antara gaya kepemimpinan transaksional terhadap kinerja karyawan didapatkan nilai t hitung $(1,420)$ kurang dari t tabel $(1,973)$ atau nilai signifikansi $(0,157)$ lebih dari alpha $(0,050)$ sehingga tidak terdapat pengaruh signifikan antara gaya kepemimpinan transaksional terhadap kinerja karyawan.

b. Uji parsial antara Need For Achivement terhadap kinerja karyawan didapatkan nilai t hitung $(5,091)$ lebih dari t tabel $(1,973)$ atau nilai signifikansi $(0,000)$ kurang dari alpha $(0,050)$ sehingga terdapat pengaruh signifikan antara Need For Achivement terhadap kinerja karyawan.

\section{Pembahasan}

\section{Analisis Regresi Linier Berganda}

Digunakannya analisis regresi linier berganda dalam penelitian ini bermaksud untuk menganalisis pengaruh gaya kepemimpinan transaksional (X1) dan Need For Achivement (X2) terhadap kinerja karyawan (Y) PDAM Kota Malang.

Hasil persamaan regresi linier berganda pada gaya kepemimpinan transaksional dan Need For Achivement terhadap kinerja karyawan adalah : $\mathrm{Y}=\mathrm{a}+\mathrm{b} 1 \mathrm{X} 1+\mathrm{b} 2 \mathrm{X} 2+$ e. Dari persamaan tersebut dapat dijabarkan sebagai berkut : $(Y=28.392$ $+0.125 \mathrm{X} 1+0.433 \mathrm{X} 2+$ e) artinya nilai konstanta (a) sebesar 28,392 menunjukkan bahwa tanpa adanya pengaruh dari gaya kepemimpinan transaksional dan Need For Achivement maka kinerja karyawan sebesar 28,392. Kemudian nilai koefisien gaya kepemimpinan transaksional (b1) sebesar 0,125 menunjukkan bahwa semakin baik gaya kepemimpinan transaksional maka akan semakin meningkatkan kinerja karyawan. Dan nilai koefisien Need For Achivement (b2) sebesar 0,433 menunjukkan bahwa semakin baik Need For Achivement maka akan semakin meningkatkan kinerja karyawan. Dari hasil regresi linear berganda yang telah dipaparkan, menunjukkan bahwa variabel gaya kepemimpinan transaksional dan Need For Achivement berpengaruh positif terhadap kinerja karyawan PDAM Kota Malang 


\section{Dwi Yulis Susanto | Gaya Kepemimpinan}

1. Pengujian hipotesis

Pengujian Hipotesis Secara parsial (Uji t) memiliki tujuan untuk menguji dari hipotesis yang menyatakan bahwa variabel gaya kepemimpinan transaksional (x1) dan Need For Achivement (x2). Secara parsial atau secara individu berpengaruh signifikan terhadap kinerja karyawan (Y) PDAM Kota Malang.

a. Hipotesis 1 (H1) : ada pengaruh positif gaya kepemimpinan transaksional terhadap kinerja karyawan

Berdasarkan hasil uji t, dimana antara gaya kepemimpinan transaksional terhadap kinerja karyawan didapatkan nilai t hitung $(1,420)$ kurang dari t tabel $(1,973)$ atau nilai signifikansi $(0,157)$ lebih dari alpha $(0,050)$ sehingga secara pasrsial tidak terdapat pengaruh signifikan antara gaya kepemimpinan transaksional terhadap kinerja karyawan PDAM Kota Malang. Hal ini berarti bahwa hipotesa yang menyatakan ada pengaruh positif gaya kepemimpinan transaksional terhadap kinerja karyawan ditolak, atau Ho diterima dan Ha ditolak.

Issak, (2014) Menyebutkan beberapa kelemahan kepemimpinan Transaksional, antara lain: (a) Pemimpin Transaksional hanya tertarik dengan prosedur dalam menentukan untuk mencapai tujuan organisasi. Dalam pikiran mereka hanya dalam bentuk membuat peraturan "boleh" atau "tidak boleh" saja. Bentuk "tidak boleh" malah biasanya lebih banyak daripada "boleh". Ini disebabkan karena selalu menafsirkan tentang prosedur dan peraturan organisasi dengan melakukan penafsiran serta pandangan yang sempit dan kaku. (b) Pemimpin transaksional mengambil jalan mudah dan pintas untuk menjalankan tugas sewaktu membuat keputusan. Golongan pimpinan tidak mau berusaha mengambil inisiatif yang lebih, untuk mencari jalan keluar dalam menyelesaikan suatu masalah secara kreatif dan inovasi. Malah sebaliknya, bawahan yang menghadapi masalah, dianggap sebagai beban organisasi, dan pemimpinnya tidak mau mendengar segala permasalahan yang ada serta mencoba mencari jalan keluarnya. Prinsip yang dipegang oleh pemimpin "Transaksional" adalah, masalah 


\section{Dwi Yulis Susanto | Gaya Kepemimpinan}

bawahan merupakan masalah pribadi bawahan itu sendiri dan tidak boleh dicampur adukkan dengan masalah organisasi. (c) Dalam aspek komunikasi, Pemimpin Transaksional lebih tertarik dengan menggunakan memo atau tidak mau berhadapan dengan bawahan secara langsung untuk mewujudkan komunikasi tatap muka. Masalah-masalah yang harus diselesaikan melalui pembicaraan tatap muka disalurkan melalui memo mereka berpendapat bahwa, melalui memo lebih berhasil untuk memperlihatkan suatu ketegasan dalam masalah-masalah yang dihadapi organisasi. (d) Kepemimpinan Transaksional ini juga lebih memperlihatkan efektivitas suatu peraturan dan disiplin daripada menggunakan pendekatan pribadi karena, mereka lebih cenderung untuk bersikap otoriter, apabila menjalankan tugasnya. Mereka juga jarang mau berkomunikasi dengan bawahan seolah-olah ada suatu gap atau suatu jurang pemisah antara pemimpin dengan bawahan dan ini secara tidak langsung akan mematikan kreativitas dan jalinan keakraban diantara bawahan dan pimpinan (Issak, 2014)

Hasil ini sejalan dengan penelitian Satrijo Budiwibowo (2014) yang melakukan penelitian tentang pengaruh gaya kepemimpinan transaksional, transformasional dan disiplin kerja terhadap kinerja guru (karyawan) di Kota Madiun. Hasil penelitian menunjukkan bahwa secara bersama-sama gaya kepemimpinan transaksional, transformasional, disiplin kerja berpengaruh terhadap kinerja guru (karyawan) di Kota Madiun. Namun secara parsial gaya kepemimpinan transaksional dan transformasional tidak berpengaruh terhadap kinerja sedangkan disiplin kerja berpengaruh paling dominan terhadap kinerja.

b. Hipotesis 2 (H2) : ada pengaruh positif Need For Achivement terhadap kinerja karyawan

Pengaruh komunikasi internal (X2) terhadap kinerja karyawan (Y) PDAM Kota Malang. Berdasarkan hasil uji t Need For Achivement terhadap kinerja karyawan didapatkan nilai $\mathrm{t}$ hitung $(5,091)$ lebih dari t tabel $(1,973)$ atau nilai signifikansi $(0,000)$ kurang dari alpha $(0,050)$ sehingga secara parsial

\section{6 | Journal An-nafs: Vol. 3 No. 1 Juni 2018}




\section{Dwi Yulis Susanto | Gaya Kepemimpinan}

terdapat pengaruh signifikan antara Need For Achivement terhadap kinerja karyawan. Hal ini berarti bahwa hipotesa yang menyatakan ada pengaruh positif Need For Achivement terhadap kinerja karyawan diterima, atau Ho ditolak dan Ha diterima.

Hasil penelitian dari Edward Satriya \& Dadang Iskandar, (2016) yang menyimpulkan bahwa berdasarkan hasil uji pengaruh baik parsial maupun simultan yang dilakukan antara variabel motivasi (Need for Achievement, need for power dan need for affiliation) terhadap kinerja diketahui bahwa masingmasing variabel yan terdapat pada motivasi berpengaruh secara parsial terhadap kinerja karyawan.

Hasil penelitian Siswandi (2013) dalam penelitiannya tentang pengaruh gaya kepemimpinan, komunikasi internal dan motivasi kerja terhadap kinerja karyawan menyimpulkan bahwa terdapat pengaruh positif dan signifikan dari variabel motivasi terhadap kinerja karyawan. sehingga dapat disimpulkan bahwa perubahan-perubahan yang terjadi pada kinerja karyawan, dipengaruhi/ditentukan oleh perubahan-perubahan dari motivasi, tetapi tidak berlaku sebaliknya. apabila motivasi mengalami peningkatan, maka secara otomatis akan diikuti oleh peningkatan variabel kinerja karyawan, dan sebaliknya.

c. Hipotesis 3 (H3) : gaya kepemimpinan transaksional dan Need For Achivement secara bersama-sa ma berpengaruh terhadap kinerja karyawan

Pengujian Hipotesis Secara Simultan (Uji F) memiliki tujuan untuk menguji dari hipotesis yang menyatakan bahwa gaya kepemimpinan transaksional (x1) dan Need For Achivement (x2) secara simultan atau secara bersama-sama berpengaruh signifikan terhadap kinerja karyawan (Y) PDAM Kota Malang.

Berdasarkan hasil uji $\mathrm{F}$ dengan tingkat signifikansi (a) = 0,05 atau 5 persen, dinyatakan bahwa gaya kepemimpinan transaksional (x1) dan Need For Achivement (x2) secara simultan berpengaruh signifikan terhadap kinerja karyawan PDAM Kota Malang. Hal ini terbukti dari nilai $\mathrm{F}$ hitung =16,219 lebih besar dari nilai $\mathrm{F}$ tabel $=3,044$. $\mathrm{R}$ square yang bernilai sebesar 0,139 


\section{Dwi Yulis Susanto | Gaya Kepemimpinan}

memiliki pengertian bahwa 0,139 persen variasi kinerja karyawan dipengaruhi oleh variabel bahwa gaya kepemimpinan transaksional dan komunikasi internbal dan sisanya sebesar 86,1 persen dipengaruhi variabel lain yang tidak disebutkan dalam penelitian ini. Hal ini berarti bahwa hipotesa yang menyatakan gaya kepemimpinan transaksional dan Need For Achivement secara bersama-sama berpengaruh positif terhadap kinerja karyawan diterima, atau Ho ditolak dan Ha diterima.

2. Variabel bebas yang berpengaruh dominan

Variabel bebas yang berpengaruh dominan terhadap variabel terikat, berdasarkan perhitungan analisis standardized coefficients beta diketahui bahwa variabel Need For Achivement memiliki nilai standardized coefficients beta terbesar dari variabel bebas gaya kepemimpinan transaksional yaitu sebesar 0,352. Ini berarti bahwa need for achivement memiliki pengaruh yang paling dominan terhadap kinerja karyawan PDAM Kota Malang.

\section{Kesimpulan}

Berdasarkan uraian dari analisis dan pembahasan yang dilakukan sebelumnya, maka berikut ini dapat diambil beberapa kesimpulannya:

1. Hasil uji hipotesis pertama menunjukkan bahwa tidak terdapat pengaruh signifikan antara gaya kepemimpinan transaksional terhadap kinerja karyawan. Tidak adanya pengaruh yang signifikan secara parsial antara variabel bebas gaya kepemimpinan transaksional terhadap variabel terikat kinerja karyawan adalah adanya variabel-variabel luaran. Kinerja karyawan itu sendiri tidak hanya dipengaruhi oleh gaya kepemimpinan tetapi menurut Mangkunegara (2006) juga dapat dipengaruhi oleh bermacam-macam faktor, seperti kompensasi/gaji yang diterima, kemampuan potensi (IQ), pendidikan, hubungan kerja, fasilitas kerja, dan faktor lainnya yang tidak penulis teliti dalam penelitian ini. Dalam penelitian ini peneliti memiliki temuan lain yakni mengapa

\section{8 | Journal An-nafs: Vol. 3 No. 1 Juni 2018}




\section{Dwi Yulis Susanto | Gaya Kepemimpinan}

gaya kepemimpinan transaksional tidak berpengaruh terhadap kinerja karyawan adalah karena adanya SOP (Standar Operasional Prosedur). (SOP) menurut pandangan Tambunan (2008) adalah pedoman yang berisi prosedurprosedur operasional yang ada dalam organisasi yang digunakan untuk memastikan, bahwa semua keputusan dan tindakan serta penggunaan fasilitas-fasilitas proses yang dilakukan oleh orang-orang di dalam organisasi berjalan secara efektif, konsisten, standard dan sistematis.

2. Hasil uji hipotesis kedua menunjukkan bahwa terdapat pengaruh signifikan antara Need For Achivement terhadap kinerja karyawan. Sehingga dapat disimpulkan bahwa perubahan-perubahan yang terjadi pada kinerja karyawan, dipengaruhi/ditentukan oleh perubahan-perubahan dari Need For Achivement, tetapi tidak berlaku sebaliknya, apabila variabel need for achivement mengalami peningkatan, maka secara otomatis akan diikuti oleh peningkatan variabel kinerja karyawan, dan sebaliknya. Need for achivement memiliki pengaruh terhadap kinerja karyawan, artinya semakin baik need for achivement maka akan semakin tinggi kinerja karyawan. Pace dan Faules (2013) menjelaskan bahwa komunikasi organisasi memiliki arti penting karena tidak hanya memberikan manfaat bagi orang-orang yang ingin memahami perilaku organisasi, tetapi juga memiliki aspek prakmatis bagi orang-orang yang ingin memperbaiki kinerjanya dalam suatu organisasi. Artinya, komunikasi organisasi dalah dijadikan sebagai salah satu cara untuk meningkatkan kinerja karyawan, karena dengan komunikasi maka pimpinan dapat memberikan pengarahan, informasi atau bimbingan agar karyawan dapat bekerja lebih baik. Sebaliknya, karyawan juga dapat berkonsultasi kepada pimpinan tentang kendala atau masalah pekerjaan yang dihadapi sehingga dapat diselesaikan dengan cepat dan tepat.

3. Hasil uji hipotesis yang ketiga menunjukkan variabel-variabel independen yakni gaya kepemimpinan transaksional dan 


\section{Dwi Yulis Susanto | Gaya Kepemimpinan}

need for achivementsecara simultan memberi pengaruh signifikan terhadap kinerja.

4. Hasil koefisien determinasi berganda ( $R$ Square) dapat diketahui bahwa kepemimpinan transaksional, dan need for achivement mempengaruhi kinerja karyawan sebesar $(0,139)$ ini berarti bahwa perubahan naik turunnya kinerja karyawan dipengaruhi oleh variabel kepemimpinan transaksional dan need for achivement sebesar 13,9\%, sedangkan besar pengaruh terhadap variabel kinerja karyawan yang ditimbulkan oleh faktor lain adalah sebesar $86,1 \%$. Besarnya persentase faktor lain yang berpengaruh terhadap kinerja karyawan dalam penelitian ini memberikan peneliti asumsi bahwa selain faktor gaya kepemimpinan dan need for achievement, faktor budaya organisasi, kompensasi, lama kerja, standard operasional prosedur, serta komunikasi juga dapat berpengaruh lebih signifikan lagi terhadap kinerja karyawan.

\section{Saran}

Dari hasil penelitian ini peneliti dapat diajukan beberapa saran yaitu:

1. Secara teori untuk gaya kepemimpinn transaksional masih sangat minim, untuk dapat memberikan wawasan dan sumbangsih pemikiran dalam psikologi industri perlu adanya penelitian yang labih banyak tentang gaya kepemimpinan transaksional dapat menjadi acuan pembanding dalam penelitian pada bidang yang sama dan bermanfaat bagi pembaca.

2. Hasil penelitian menunjukkan secara bersama-sama kepemimpinan dan need for achievement berpengaruh signifikan terhadap kinerja karyawan, tentunya hal ini dapat terus ditingkatkan dan dipertahankan baik oleh pimpinan maupun karyawan. Hasil penelitian juga menunjukan bahwa tidak ada pengaruh dari gaya kepemimpinan transaksional terhadap kinerja karyawan, hal ini perlu mendapat perhatian 


\section{Dwi Yulis Susanto | Gaya Kepemimpinan}

perusahaan khususnya bagi pimpinan agar dapat menggunakan/ menerapkan gaya kepemimpinan transaksional karena semakin erat hubungannya maka akan semakin baik pula kinerja karyawannya.

3. Berdasarkan analisis pula diketahui bahwa need for achievement merupakan variabel yang berpengaruh dominan terhadap kinerja karyawan PDAM Kota Malang, berarti kebutuhan berprestasi merupakan salah satu hal yang sangat penting bagi kinerja karyawan, seyogyanya bagi pimpinan dan karyawan agar terus meningkatkan kebutuhan berprestasinya secara terus menerus dengan tidak melupakan variabel lain yang juga sama penting.

4. Bagi para peneliti selanjutnya, untuk lebih mengembangkan penelitian dengan mengganti atau menambahkan variabel lain dengan menggunakan jenis atau macam kepemimpinan yang lainnya serta variabel lain seperti pelatihan, standar operasional prosedur, kompensasi/gaji yang diterima, kemampuan potensi (IQ), motivasi kerja, stress kerja dan budaya organisasi. Serta menggunakan tempat lain sebagai objek penelitian seperti rumah sakit, bank, perguruan tinggi, kantor instansi, lainnya, dan lain sebagainya. 


\section{Dwi Yulis Susanto | Gaya Kepemimpinan}

\section{Daftar Pustaka}

Bangun, W. (2012). Manajemen Sumber Daya Manusia. Jakarta: Erlangga.

Brahmasari, Ida Ayu. Agus Suprayetno. (2008). Pengaruh Motivasi Kerja, Kepemimpinan Dan Budaya Organisasi Terhadap Kepuasan Kerja Karyawan Serta Dampaknya Pada Kinerja Perusahaan (Studi Kasus Pada PT. Pei Hai International Wiratama Indonesia). Jurnal Manajemen Dan Kewirausahaan, Vol.10, No.2, Surabaya.

Davis, Keith, Newstrom, dan John W. (2004). Perilaku Dalam Organisasi.Edisi Ketujuh Bahasa Indonesia. Jilid I. Jakarta : Penerbit Erlangga.

Darmawan, D. (2013). Merode penelitian kuantitatif. Bandung : PT Remaja Rosdakarya

Fanni, A.I.(2013) Pengaruh Gaya Kepemimpinan Transformasional Dan Transaksional Terhadap Kinerja Pegawai Departemen Sdm Pt. Semen Gresik (Persero) Tbk. Universitas Negeri Surabaya Jurnal Ilmu Manajemen Volume 1 Nomor 2 Maret 2013.

Gibson, J.L. (2000). Organisasi, Perilaku, Struktur dan Proses. Edisi ke-5. Cetakan ke-3. Jakarta: Penerbit Erlangga

Ginting, Paham dan Syafrizal Helmi Situmorang. (2008). Filsafat Ilmu dan Metode Riset, Medan : USU Press.

Gibson, James L, John M. Ivancevich dan James H. Donnelly Jr, 2003. Organizations: Behaviour, Structure and Process, McGraw-Hill Companies Inc, Boston.

Nitisemito, A.S. (2008). Manajemen Personalia (Manajemen Sumber Daya Manusia. Edisi Kelima, Cetakan Keempat Belas. Jakarta : Ghalia Indonesia.

Mangkunegara, A.P. (2005). Evaluasi Kinerja. Bandung : Refika Aditama. . (2005). PPSDM. Bandung: Refika Aditama.

Sehfudin,A. (2011). Pengaruh Gaya Kepemimpinan, Komunikasi Organisasi Dan Motivasi Kerja Karyawan (Studi Pada Bank Tabungan Pensiunan Nasional Cabang Semarang), Fakultas Ekonomi Universitas Diponegoro, Semarang.

Sofyandi, H. (2008). Manajemen Sumber Daya Manusia. Edisi Pertama, Yogyakarta: Graha Ilmu.

Sofyandi, H. (2008). Manajemen Sumber Daya Manusia. Edisi Pertama, Yogyakarta : Graha Ilmu. 


\section{Dwi Yulis Susanto | Gaya Kepemimpinan}

jn Hasibuan, M.S.P. (2011). Manajemen Sumber Daya Manusia, Edisi Revisi. Jakarta: Pt. Bumi Aksara.

Issakh, H.I. (2014). Kepemimpinan Dalam Melakukan Perubahan Organisasi. Jakarta : In Media.

(2014). Pengantar Manajemen. Jakarta : In Media.

I Komang Prawina Wijaya dan Made Surya Putra. (2014), Pengaruh Kepemimpinan Transaksional Dan Stres Kerja Terhadap Kepuasan Kerja Karyawan Pt. Panca Dewata Denpasar Bali, E-Jurnal Manajemen Universitas Udayana Vol 3, No 10 (2014), (diakses pada 23 April 2016 pukul 20.00 WIB)

Kartono, K. (2005). Pemimpin Dan Kepemimpinan. Jakarta : PT. Raja Grafindo Persada

Pace, R. Wayne dan Faules, Don F, 2013, Komunikasi Organisasi Strategi Meningkatkan Kinerja Perusahaan, Terjemahan: Dedy Mulyana, Cetakan kedelapan, Bandung: Remaja Rosdakarya.

Panggabean. (2007). Manajemen Sumber Daya Manusia. Bogor : Ghalia Indonesia

Riniwati, Harsuko. (2011). Mendongkrak Motivasi Dan Kinerja: Pendekatan Pemberdayaan SDM. Malang : UB Press.

Rivai Dan Basri, (2005). Performance Appraisal. Cetakan Pertama. Jakarta : PT Raja Grafindo Persada.

Rivai, V. (2011). Manajemen Sumber Daya Manusia Untuk Perusahaan Dari Teori Ke Praktek. Jakarta : PT. Rajagrafindo Persada.

Robbins SP, dan judge. (2007). Perilaku organisasi. Jakarta : Salemba Empat (2008). Perilaku Organisasi Edisi Ke-12. Jakarta: Salemba Empat.

Boston: Pearson. (2011). Organizational Behavior. 14th Ed.

Robbins, S.P. (2006). Perilaku Organisasi. Edisi Kesepuluh. Jakarta : Pt. Indeks Kelompok Gramedia. (2008). Perilaku Organiasi. Edisi Bahasa Indonesia, Alih Bahasa, Benyamin Molan (Edisi Ke-10). Jakarta : Indeks. Rosnani, T. (2012) Pengaruh Kepemimpinan Transaksional Dan Kepemimpinan Transformasional Terhadap Kepuasan Kerja Dan Kinerja Dosen Universitas Tanjungpura Pontianak. Jurnal Ekonomi Bisnis Dan Kewirausahaan 2012, Vol. 3, No. 1, 1-28 1 


\section{Dwi Yulis Susanto | Gaya Kepemimpinan}

Singgih, S. (2009) Panduan Lengkap Menguasai Statistik Dengan Spss 17. Jakarta: Pt Elex Media Komputindo.

Sedarmayanti. (2007). Manajemen Sumber Daya Manusia : Reformasi Dan Manajemen Pegawai Negeri Sipil. Bandung: Refika Aditama.

Siswandi. (2013) Pengaruh Gaya Kepemimpinan, Need For Achivement Dan Motivasi Kerja Terhadap Kinerja Karyawan Siswandi Jurnal Publikasi Program Studi Manajemen Fakultas Ekonomi \& Bisnis, Universitas Dian Nuswantoro Semarang

Situmorang, S. H. (2010). Analisa Data. Medan: Usu Press

Sugiono. (2011). Metode Penelitian Kuantitatif. Bandung : CV. Alfabeta.

(2012). Metode Penelitian Kuantitatif Kualitatif Dan R\&D. Bandung: Alfabeta.

(2004). Metode Penelitian Bisnis. Bandung : Penerbit Cv. Alfabeta.

Sunyoto, A. (2008). Manajemen Sumber Daya Manusia. Jakarta: Ipwi

Suryabrata, S. (2005). Pengembangan Alat Ukur Psikologis. Yogyakarta: Andi.

Suryabrata, S. (1994). Metodologi Penelitian. Jakarta : Pt Rajagrafindo Persada.

Tambunan, T. (2008). Ukuran Daya Saing Koperasi Dan Ukm. Jurnal Pusat Studi Industri Dan UKM.99

Thoha, M. (2007). Kepemimpinan Dalam Manajemen. Edisi 12, Jakarta : PT. Raja Grafindo Persada.

Yukl, G. (2010). Kepemimpinan dalam organisasi. Edisi kelima. Jakarta : PT. Indeks

Yulianita, N. (2005). Dasar-Dasar Public Relations. Bandung : Pusat Penerbitan Universitas Bandung

Yuwono, Dkk. (2005). Psikologi Industri Dan Organisasi. Surabaya : Universitas Airlangga

Http://Www.Kemenkeu.Go.Id/Berita/Indeks-Daya-Saing-Global-

Indonesia-Duduki-Peringkat-37-Dari-140-Negara. Online (Diakses Pada, 05 April 2016,)

Http://Www.Voaindonesia.Com/Content/Undp-Indeks-

Pembangunan-Manusia-Indonesia-Alami-

Kemajuan/3110936.Html. Online (DIakses Pada, 05 April 2016) 